\title{
Hubungan Antara Cara Belajar dan Motivasi Belajar Siswa dengan Hasil Belajar Biologi Siswa SMA di Kota Makassar
}

\author{
Nurmiati \\ Universitas Sulawesi Barat \\ e-mail: nurmi_81@yahoo.co.id
}

\begin{abstract}
Abstrak
Siswa yang memiliki cara belajar yang baik, dapat mencerminkan siswa yang memiliki motivasi belajar yang tinggi sehingga akan meningkatkan hasil belajar siswa.Tujuan penelitian ini adalah (i) untuk mengetahui hubungan antara cara belajar dengan hasil belajar siswa SMA di kota Makassar, (ii) untuk mengetahui hubungan antara motivasi belajar dengan hasil belajar siswa SMA di kota Makassar, (iii) untuk mengetahui hubungan antara cara belajar dan motivasi belajar secara bersama-sama dengan hasil belajar siswa SMA di kota Makassar. Jenis penelitian ini adalah penelitian éx-post facto" bersifat korelasional dengan teknik pengumpulan data menggunakan angket dan dokumentasi.Hasil penelitian menunjukkan bahwa (i) cara belajar siswa SMA Negeri di kota Makassar berada pada kategori sedang, dan ada hubungan dengan hasil belajar biologi siswa SMA Negeri di kota Makassar, (ii) motivasi belajar siswa SMA Negeri di kota Makassar berada pada kategori sedang, dan ada hubungan dengan hasil belajar biologi siswa SMA Negeri di kota Makassar, (iii) hasil belajar siswa SMA Negeri di kota Makassar berada pada kategori sedang, dan ada hubungan antara cara belajar dan motivasi belajar secara bersama-sama dengan hasil belajar biologi siswa SMA Negeri di kota Makassar.Kata kunci-35 kata kunci, Algoritma A, algoritma B, kompleksitas
\end{abstract}

\section{PENDAHULUAN}

Cara belajar merupakan cara bagaimana siswa melakukan kegiatan untuk menambah pengetahuan dan pengalaman. Untuk mencapai hasil belajar yang baik diperlukan cara belajar yang baik pula, namun pada kenyataannya masih ada siswa yang mempunyai cara belajar yang buruk. Hal ini terlihat baik pada saat kegiatan belajar di kelas ataupun di rumah. Misalnya saja ketika diberikan tugas rumah (PR) masih saja ada siswa yang belum mengerjakan sehingga siswa harus mengerjakannya di sekolah atau terlihat pada saat ulangan masih ada siswa yang berusaha untuk mencontek. Kenyataan demikian memperlihatkan bahwa siswa belum mempunyai cara belajar yang baik sehingga hasil belajar yang dicapai manjadi kurang maksimal.

Buruknya cara belajar merupakan salah satu faktor penyebab rendahnya hasil belajar sehingga menyebabkan menurunnya mutu pendidikan. Cara dan kebiasaan belajar yang tepat akan menentukan hasil yang memuaskan, sebaliknya cara belajar yang buruk akan memberikan hasil yang kurang memuaskan (Hamalik, 2002). Sejalan dengan pendapat Slameto (2010) 
JURNAL SAINTIFIK VOL.3 NO.1, JANUARI 2017

mengemukakan bahwa, faktor cara belajar yang buruk merupakan penyebab masih banyaknya siswa yang sebenarnya pandai tetapi hanya meraih prestasi yang tidak lebih baik dari siswa yang sebenarnya kurang pandai tetapi mampu meraih prestasi yang tinggi karena mempunyai cara belajar yang baik. Banyak siswa gagal atau tidak mendapat hasil yang baik dalam belajar karena tidak mengetahui cara-cara belajar yang efektif.

Hasil penelitian sebelumnya yang dilakukan oleh Nur (2011) dengan variabel yang berbeda dengan penelitian yang akan dilakukan oleh peneliti yaitu kecerdasan emosional dan kedisiplinan belajar berhubungan positif terhadap hasil belajar siswa SMA di kota Makassar. Demikian pula penelitian yang dilakukan oleh Zainullah (2010) menunjukkan bahwa cara belajar dan motivasi berprestasi baik secara bersama-sama maupun terpisah mempunyai pengaruh yang sangat kecil terhadap prestasi belajar pendidikan matematika 1, sehingga dikategorikan tidak berhubungan signifikan.

Berdasarkan hasil penelitian tersebut maka peneliti berminat melakukan penelitian yang sama dengan variabel cara dan motivasi belajar siswa dengan hasil belajar siswa. Berdasarkan pengamatan penulis, secara umum cara belajar dan motivasi belajar siswa SMA di kota Makassar tergolong masih rendah. Ini tergambar dari masih banyaknya siswa yang mendapat bantuan pada saat mengikuti Ujian Akhir Nasional (UAN) dari pihak tertentu.

Cara dan motivasi belajar hanya sebagian dari variabel yang berhubungan dengan hasil belajar yang dicapai oleh siswa. Masih banyak variabel lain yang mempengaruhi antara lain minat belajar, lingkungan, sarana, prasarana, guru, dan lain sebagainya. Jadi dalam penelitian ini hanya meneliti tentang cara belajar dan motivasi belajar, sehubungan dengan usaha peningkatan hasil belajar siswa.

\section{METODE PENELITIAN}

Makalah hendaknya memuat tulisan yang berisi 1.Pendahuluan, 2. Metode Penelitian (bisa meliputi analisa, arsitektur, metode yang dipakai untuk menyelesaikan masalah, implementasi), 3. Hasil dan Pembahasan, 4. Kesimpulan dan 5. Saran (future works) yg berisi penelitian lanjut di masa mendatang. Pada setiap paragraph bisa terdiri dari beberapa subparagraph yang dituliskan dengan penomoran angka arab seperti yang ditunjukkan section berikut ini. Jumlah halaman minimum 10 halaman dan maksimum 12 halaman ukuran A4.

\section{Jenis Penelitian}

Jenis penelitian ini adalah survei yang bersifat "ex-post facto" dimana data diperoleh berdasarkan gejala alam atau fenomena tertentu yang sudah terjadi.

\section{Variabel Penelitian}

Variabel dalam penelitian terdiri dari dua variabel independent (bebas) yakni cara belajar siswa (X1) dan motivasi belajar siswa (X2), serta satu variabel terikat yaitu hasil belajar biologi (Y)

\section{Populasi dan Sampel}

Populasi dalam penelitian ini adalah seluruh siswa SMA di Kota Makassar tahun ajaran 2012/2013. Sampel penelitian ini adalah siswa pada tiga SMA di Kota Makassar tahun ajaran $2012 / 2013$. 
JURNAL SAINTIFIK VOL 3 NO.1, JANUARI 2017

Instrumen Penelitian

Instrumen yang digunakan dalam penelitian ini adalah kuesioner (angket) dan dokumentasi dan sebelum digunakan terlebih dahulu dilakukan uji validitas dan uji reliabilitas.

Teknik Analisis Data

Data yang diperoleh dari lapangan, baik data tentang cara belajar siswa dan motivasi belajar siswa maupun hasil belajar siswa akan dianalisis secara kuantitatif, yakni menggunakan teknik statistik, baik statistik deskriptif maupun statistik inferensial.

\section{HASIL DAN PEMBAHASAN}

Analisis Deskriptif

Hasil analisis deskriptif skor cara belajar siswa SMA Negeri di kota Makassar ditampilkan pada tabel berikut:

Tabel 1. Distribusi Frekuensi Cara Belajar Siswa SMA Negeri di kota Makassar

\begin{tabular}{|c|c|c|c|}
\hline Interval kelas & Frekuensi & Persentase & Kategori \\
\hline $60-74$ & 18 & 5.3 & Sangat rendah \\
\hline $75-89$ & 143 & 42.1 & Rendah \\
\hline $90-104$ & 151 & 44.4 & Sedang \\
\hline $105-119$ & 23 & 6.7 & Tinggi \\
\hline $120-134$ & 5 & 1.5 & Sangat tinggi \\
\hline Jumlah & 340 & 100 & \\
\hline
\end{tabular}

Dari Tabel 1 dapat dilihat skor cara belajar siswa SMA Negeri di kota Makassar. Apabila data diklasifikasikan menjadi 5 kelompok yang terdiri dari kelompok sangat rendah, rendah, sedang, tinggi, dan sangat tinggi, berdasarkan tabel diatas maka terdapat 5.3\% responden yang mempunyai tingkat cara belajar sangat rendah, $42.1 \%$ responden yang mempunyai tingkat cara belajar rendah, $44.4 \%$ responden yang memiliki tingkat cara belajar sedang, $6.7 \%$ responden yang mempunyai tingkat cara belajar tinggi, dan $1.5 \%$ responden yang mempunyai tingkat cara belajar sangat tinggi. Setelah melihat banyaknya responden yang berada pada interval kelas $(90$ - 104) yaitu 151 responden atau $44.4 \%$ dengan tingkat cara belajar sedang, maka dapat disimpulkan bahwa cara belajar siswa SMA Negeri di kota Makassar dapat diklasifikasikan pada tingkat cara belajar sedang.

Data yang terkumpul melalui instrumen penelitian yang berupa kuesioner/angket mengenai skor motivasi belajar siswa SMA Negeri di kota Makassar

Tabel 2. Distribusi Frekuensi Variabel Motivasi Belajar Siswa SMA Negeri di kota Makassar

\begin{tabular}{|c|r|r|c|}
\hline Interval kelas & Frekuensi & Persentase & Kategori \\
\hline $75-89$ & 10 & 2.9 & Sangat rendah \\
\hline
\end{tabular}


JURNAL SAINTIFIK VOL.3 NO.1, JANUARI 2017

\begin{tabular}{|c|r|r|c|}
\hline $90-104$ & 78 & 23.0 & Rendah \\
$105-119$ & 173 & 50.9 & Sedang \\
$120-134$ & 73 & 21.4 & Tinggi \\
$135-149$ & 6 & 1.8 & Sangat tinggi \\
\hline Jumlah & 340 & 100 & \\
\hline
\end{tabular}

Dari tabel 2 dapat diperoleh informasi tentang skor data motivasi belajar siswa SMA Negeri di kota Makassar. Apabila data diklasifikasikan menjadi 5 kelompok yang terdiri dari kelompok sangat rendah, rendah, sedang, tinggi, dan sangat tinggi, berdasarkan tabel diatas maka terdapat $2.9 \%$ responden yang mempunyai tingkat motivasi belajar sangat rendah, 23\% responden yang mempunyai tingkat motivasi belajar rendah, $50.9 \%$ responden yang memiliki tingkat motivasi belajar sedang, $21.4 \%$ responden yang mempunyai tingkat motivasi belajar tinggi, dan $1.8 \%$ responden yang mempunyai tingkat motivasi belajar sangat tinggi. Setelah melihat banyaknya responden yang berada pada interval kelas $105-119$ yaitu 173 responden atau 50.9\% dengan tingkat motivasi belajar sedang, maka dapat disimpulkan bahwa motivasi belajar siswa SMA Negeri di kota Makassar dapat diklasifikasikan pada tingkat motivasi belajar sedang.

Distribusi frekuensi dan persentase hasil belajar siswa SMA Negeri di kota Makassar dapat dilihat pada tabel 3 berikut ini.

Tabel 3. Distribusi Frekuensi Skor Hasil Belajar Biologi Siswa SMA Negeri di Kota Makassar

\begin{tabular}{|c|r|r|c|}
\hline Interval kelas & Frekuensi & Persentase & Kategori \\
\hline $50-60$ & 34 & 10.0 & Sangat rendah \\
$61-71$ & 61 & 17.9 & Rendah \\
$72-82$ & 143 & 42.1 & Sedang \\
$83-93$ & 86 & 25.3 & Tinggi \\
$94-104$ & 16 & 4.7 & Sangat tinggi \\
\hline Jumlah & 340 & 100 & \\
\hline
\end{tabular}

Berdasarkan tabel di atas diporeleh informasi tentang data skor hasil belajar biologi siswa SMA Negeri di kota Makassar. Apabila data diklasifikasikan menjadi 5 kelompok yang terdiri dari kelompok sangat rendah, rendah, sedang, tinggi, dan sangat tinggi, berdasarkan tabel diatas maka terdapat $10 \%$ responden yang mempunyai tingkat hasil belajar sangat rendah, $17.9 \%$ responden yang mempunyai tingkat hasil belajar rendah, $42.1 \%$ responden yang memiliki tingkat hasil belajar sedang, $25.3 \%$ responden yang mempunyai tingkat hasil belajar tinggi, dan $4.7 \%$ responden yang mempunyai tingkat hasil belajar sangat tinggi. Setelah melihat banyaknya responden yang berada pada interval kelas 72 - 82 yaitu 143 responden atau $42.1 \%$ dengan tingkat hasil belajar biologi sedang, maka dapat disimpulkan bahwa hasil belajar biologi siswa SMA Negeri di kota Makassar dapat diklasifikasikan pada tingkat hasil belajar biologi sedang.

\section{Analisis Inferensial}

Analisis inferensial ini dilakukan dengan dua tujuan, yaitu untuk memperoleh jawaban terhadap pertanyaan-pertanyaan penelitian yang belum terjawab melalui analisis deskriptif dan untuk menguji hipotesis penelitian. 
a. Hubungan Cara Belajar dan Hasil Belajar

Data hasil pengukuran cara belajar dengan hasil belajar biologi siswa SMA Negeri di kota Makassar diolah dengan menggunakan program computer Statistic Package Social Science (SPSS) 20.0 diperoleh hasil koefisien korelasi $\mathrm{r}_{\text {hitung }}=0.225$ (Lampiran 4) berdasarkan pedoman interupretasi koefisien korelasi termasuk pada kategori rendah (Tabel 3.4). Selanjutnya diuji signifikan dengan membandingkan harga $r_{\text {tabel }}$ dengan taraf signifikansi 5\% dengan nilai $\mathrm{p}=0.000$ untuk $\mathrm{n}=340$, maka harga $\mathrm{r}_{\text {tabel }}=0.113$ dengan ketentuan bila $\mathrm{r}_{\text {hitung }}$ lebih kecil dari $\mathrm{r}_{\text {tabel}}$, maka $\mathrm{H}_{0}$ diterima, dan $\mathrm{H}_{1}$ diterima, tetapi sebaliknya bila $\mathrm{r}_{\text {hitung }}$ lebih besar dari $r_{\text {tabel }}\left(r_{h}>r_{t}\right)$ maka $H_{1}$ diterima. Dari hasil perhitungan ternyata $r_{\text {hitung }}>r_{\text {tabel }}$ maka $\mathrm{H}_{1}$ diterima, dengan demikian dapat disimpulkan bahwa ada hubungan antara cara belajar dengan hasil belajar siswa SMA Negeri di kota Makassar.

b. Hubungan Motivasi Belajar dan Hasil Belajar

Data hasil pengukuran motivasi belajar dengan hasil belajar biologi siswa SMA Negeri di kota Makassar diolah dengan menggunakan program computer Statistic Package Social Science (SPSS) 20.0 diperoleh hasil koefisien korelasi $r_{\text {hitung }}=0.208$ (Lampiran 4) berdasarkan pedoman interpretasi koefisien korelasi termasuk pada kategori rendah (Tabel 3.4). Selanjutnya diuji signifikan dengan membandingkan harga $\mathrm{r}_{\text {tabel }}$ dengan taraf signifikansi $5 \%$ dengan nilai $\mathrm{p}=0.000$ untuk $\mathrm{n}=340$, maka harga $\mathrm{r}_{\text {tabel }}=0.113$ dengan ketentuan bila $\mathrm{r}_{\text {hitung }}$ lebih kecil dari $\mathrm{r}_{\text {tabel }}$, maka $\mathrm{H}_{0}$ diterima, dan $\mathrm{H}_{1}$ diterima, tetapi sebaliknya bila $\mathrm{r}_{\text {hitung }}$ lebih besar dari $\mathrm{r}_{\text {tabel }}\left(\mathrm{r}_{\mathrm{h}}>\mathrm{r}_{\mathrm{t}}\right)$ maka $\mathrm{H}_{1}$ diterima. Dari hasil perhitungan ternyata $\mathrm{r}_{\text {hitung }}>\mathrm{r}_{\text {tabel }}$ maka $\mathrm{H}_{1}$ diterima dengan demikian dapat disimpulkan bahwa ada hubungan antara motivasi belajar dengan hasil belajar siswa SMA Negeri di kota Makassar.

c. Hubungan antara Cara Belajar dan Motivasi Belajar Secara Bersama-sama dengan Hasil Belajar Biologi

Berdasarkan hasil pengukuran data cara belajar dan motivasi belajar dalam kaitannya dengan hasil belajar biologi diolah dengan menggunakan SPSS 17.0 diperoleh hasil koefisien korelasi rhitung $=0.243$ (Lampiran 4) berdasarkan pedoman interpretasi koefisien korelasi termasuk pada kategori rendah (Tabel 3.4), dengan taraf signifikansi $5 \%$ dengan nilai $\mathrm{p}=0.000$ untuk $\mathrm{n}=340$, maka harga rtabel $=0.113$, jadi terdapat korelasi positif antara cara belajar dan motivasi belajar secara bersama-sama dengan hasil belajar biologi siswa SMA Negeri di kota Makassar. Untuk mengetahui apakah koefisien korelasi tersebut dapat digeneralisasikan atau tidak maka harus diuji signifikansinya dengan uji-F. Dengan ketentuan Fhitung $>$ Ftabel, dimana Fhitung $=10.606$ (Lampiran 4) dan Ftabel $=3.02$ dengan nilai $p=0.000$ taraf signifikansi $5 \%$. Dari perhitungan tersebut ternyata Fhitung $>$ Ftabel $(10.606>3.02)$ maka dapat dinyatakan bahwa korelasi ganda tersebut signifikan dan dapat diberlakukan dimana sampel diambil. Untuk memprediksi kualitas hasil belajar biologi maka digunakan analisis regresi linier ganda. Berdasarkan hasil perhitungan dengan menggunakan SPSS 20.0 maka harga $\mathrm{b} 0=51.179$, $\mathrm{b} 1=0.150$, dan $\mathrm{b} 2=0.107$. Jadi persamaan regresinya adalah $\hat{\mathrm{Y}}=51.179+0.150 \mathrm{X} 1+$ $0.107 \mathrm{X} 2$. Bila cara belajar dan motivasi belajar ditingkatkan sampai nilai 150 (5 skor tertinggi x 30 jumlah butir instrumen), maka hasil belajar biologi akan menjadi 89.73.

\section{KESIMPULAN}


JURNAL SAINTIFIK VOL.3 NO.1, JANUARI 2017

Berdasarkan kajian teori dan hasil analisis data yang telah diuraikan sebelumnya, maka dirumuskan beberapa kesimpulan penelitian sebagai berikut:

1. Cara belajar siswa SMA Negeri di kota Makassar berada pada kategori sedang dengan jumlah responden sebesar 151 atau 44.4\% siswa, interpretasi koefisien korelasi diperoleh nilai sebesar 0.225 dan $p=0.000$, maka dapat disimpulkan ada hubungan dengan hasil belajar biologi siswa SMA Negeri di kota Makassar.

2. Motivasi belajar siswa SMA Negeri di kota Makassar berada pada kategori sedang dengan jumlah responden 173 atau 50.9\% siswa, interpretasi koefisien korelasi diperoleh nilai sebesar 0.208 dan $\mathrm{p}=0.000$, maka dapat disimpulkan ada hubungan dengan hasil belajar biologi siswa SMA Negeri di kota Makassar.

3. Hasil belajar siswa SMA Negeri di kota Makassar berada pada kategori sedang dengan jumlah responden 143 atau 42.1\% siswa, dan interpretasi koefisien korelasi diperoleh nilai sebesar 0.243 , maka dapat disimpulkan ada hubungan antara cara belajar dan motivasi belajar secara bersama-sama dengan hasil belajar biologi siswa SMA Negeri di kota Makassar.

\section{DAFTAR PUSTAKA}

Andriani, H. 2009. Hubungan Motivasi Belajar dan Prestasi Akademik Mahasiswa S1Keperawatan Sekolah Tinggi Ilmu Kesehatan Dian Husada Mojokerto. (http://www.dianhusada.ac.id/jurnalimg/jurper1-3-hena.pdf, Diakses 16 july 2013).

Arikunto, S. 2009. Dasar-dasar Evaluasi Pendidikan. Jakarta: Bumi Aksara.

Djamarah, BS. 2006. Strategi Belajar Mengajar. Jakarta: Rineka Cipta

Dimyati \& Mudjiono. 2006. Belajar dan Pembelajaran. Jakarta: Rineka Cipta.

Djumariah, 2011. Peningkatan Motivasi dan Hasil Belajar Biologi Melalui Pendekatan pengajuan Masalah dengan Media Audiovisual pada Siswa Kelas XI SMA Negeri 1 Bajo Kabupaten Luwu. Tesis. Program Pascasarjana Universitas Negeri Makassar.

Emzir. 2011. Metodologi Penelitian Pendidikan Kuantitatif dan Kualitatif. Jakarta: Raja Grafindo Persada.

Fathurrohman, P., Sutikno, S. 2010. Strategi Belajar Mengajar. Bandung: Refika Aditama.

Hamalik, O. 2008. Perencanaan Pengajaran Berdasarkan Pendekatan Sistem. Jakarta: Bumi Aksara.

Hamalik, O. 2005. Kurikulum dan Pembelajaran. Jakarta: Bumi Antariksa.

Hamalik, O. 2002. Psikologi Belajar dan Mengajar. Bandung: Sinar Baru.

Jusmiarni, 2012. Peningkatan Aktivitas dan Hasil Belajar Biologi Melalui Model Pembelajaran Tipe Team Assested Individualization (TAI) pada Siswa Kelas VIII SMPN 2 Bontolempangan Kab. Gowa. Tesis. Program Pascasarjana Universitas Negeri Makassar.

Mappeasse, Y. 2009. Pengaruh Cara dan Motivasi Belajar terhadap Hasil Belajar Programmable Logic Controller (PLC) siswa Kelas III Jurusan Listrik SMK Negeri 5 Makassar. Medtek, (Online), vol. 1, No. 2 (http://ft-unm.net/medtek/Jurnal\%20Medtek\%20Vo.\%201_No.2 _Oktober\%202009/M.\%20Yusuf\%20Mappeasse.pdf, Diakses (13 july 2013)

Nasution. 2011. Berbagai Pendekatan dalam Proses Belajar dan Mengajar. Jakarta: Bumi Aksara.

Nur, E. 2011. Hubungan Kecerdasan Emosional dan Kedisiplinan Belajar Terhadap Hasil Belajar Biologi Siswa SMA Negeri di Kota Makassar. Tesis. Program Pasca Sarjana Universitas Negeri Makassar. 
JURNAL SAINTIFIK VOL 3 NO.1, JANUARI 2017

Purwanto, N. 2010. Psikologi Pendidikan. Bandung: Remaja Rosdakarya.

Ratna, N. 2013. Hubungan Motivasi Belajar dengan Hasil Belajar siswa pada Mata Pelajaran PKn Di SMP Negeri 77 Jakarta. (http://skripsippknunj.com/wpcontent/uploads/2013/02/JURNAL-Niken-Ratna.pdf, Diakses 16 july 2013).

Riyanto. 2009. Paradigam Baru Pembelajaran sebagai Referensi bagi Pendidik dalam Implementasi Pembelajaran yang Efektif dan Berkualitas. Jakarta: Kencana Prenada Media Group.

Rusman. 2010. Model-model Pembelajaran. Jakarta: Rajagrafindo Persada.

Sanjaya. 2009. Perencanaan dan Desain Sistem Pembelajaran. Jakarta: Kencana Prenada Media Group.

Sanjaya, Wina. 2008. Strategi Pembelajaran Berorientasi Standar Proses Pendidikan. Jakarta: Kencana Prenada Media Group.

Santrock, Jhon W. 2007. Psikologi Pendidikan. Jakarta: Kencana.

Sardiman, 2010. Interaksi dan Motivasi Belajar Mengajar. Jakarta: PT Raja Grafindo Persada.

Sardiman A. M. 2006. Interaksi dan Motivasi Belajar Mengajar. Jakarta: Rajawali Pres.

Slameto. 2010. Belajar dan Faktor-faktor yang Mempengaruhinya. Jakarta: Rineka Cipta.

Sudjana, N. 2005. Penilaian Hasil Belajar Mengajar. Bandung: PT Rosdakarya.

Sudjana, N. 2010. Penilaian Hasil Belajar Mengajar. Bandung: PT Rosdakarya.

Sugiyono. 2009. Metode Penelitian Kuantitatif Kualitatif dan R\&D. Bandung: Alfabeta.

Suyono. 2011. Belajar dan Pembelajaran. Bandung: Remaja Rosdakarya.

Tim Penyusun Kamus Pusat Pengembangan dan Pembinaan Bahasa. 2003. Kamus Besar Bahasa Indonesia. Jakarta: Balai Pustaka.

Tiro, Muhammad Arif. 2011. Analisis Korelasi dan Regresi. Makassar: Andira Publisher.

Triatno. 2010. Mendesain Model Pembelajaran Inovatif-Progresif. Jakarta: Kencana Prenada Media Group.

Uno, H. 2011. Teori Motivasi dan Pengukurannya. Jakarta: Bumi Aksara.

Undang-undang Republik Indonesia No. 20 Tahun 2003 tentang Sistem Pendidikan Nasional.

Zainullah, A. 2010. Hubungan antara Cara Belajar dan Motivasi Berprestasi dengan Prestasi Belajar Pendidikan Matematika I Mahasiswa S1 PGSD Universitas Terbuka. Jurnal Kependidikan Interaksi, (Online), Tahun 5, No. 5 (http://utsurabaya.files.wordpress.com/2010/08/zainullah-motivasi-berprestasi1.pdf. Diakses pada tanggal 2 februari 2013).

Yulianto, D. 2012. Pengaruh Cara Belajar dan Motivasi Belajar Terhadap Prestasi Belajar Siswa pada Standar Kompotensi Melakukan Prosedur Administrasi Kelas X Program Keahlian Administrasi Perkantoran SMK Negeri 2 Purworejo. Skripsi. Yokgyakarta. Universitas Negeri Yogyakarta. (http://eprints.uny.ac.id/8743/, Diakses 13 july 2013). 